УДК 796.08.

https://doi.org/10.36906/FKS-2021/96

Старкова Е.В., канд. пед. наук;

Юдина Р.Н., канд. психол. наук;

Хисматулина К.А.

Пермский государственный гуманитарно-педагогический университет, г. Пермь, Россия

\title{
ПРОФЕССИОНАЛЬНЫЕ ЗАТРУДНЕНИЯ ТРЕНЕРОВ ПО ИГРОВЫМ И НЕИГРОВЫМ ВИДАМ СПОРТА
}

Аннотация. В статье представлены результаты проведенного исследования по выявлению профессиональных затруднений тренеров по игровым и неигровым видам спорта. Проведенное исследование свидетельствует о наличии специфических трудностей в профессиональной деятельности, связанные со специфическими особенностями вида спорта. Полученные результаты позволят разработать практические рекомендации по совершенствованию образовательного процесса по программам высшего и дополнительного образования по направлению «Физическая культура и спорт».

Ключевые слова: профессиональные затруднения, тренер, игровые и неигровые виды спорта.

Starkova E.V., Ph.D.;

Yudina R.N., Ph.D.;

Khismatulina K.A.

Perm State University of Humanities and Education,

Perm, Russia

\section{PROFESSIONAL DIFFICULTIES \\ OF PLAYING AND NON-PLAYING SPORTS COACHES}

Annotation. The article presents the results of the study to identify the professional difficulties of coaches in playing and non-playing sports. The conducted research indicates the presence of specific difficulties in professional activity associated with the specific features of the sport. The results obtained will make it possible to develop practical recommendations for improving the educational process under the programs of higher and additional education in the direction of "Physical culture and sports".

Keywords: professional difficulties, coach, playing and non-playing sports.

Проблема выявления профессиональных затруднений тренеров по видам спорта и поиска путей их преодоления остается актуальной и на современном этапе развития социального института спорта. Специалистами исследовались вопросы удовлетворенности тренеров спортивных школ своей профессиональной деятельностью, успешности деятельности тренера, определения психологи-педагогических условий преодоления профессиональных затруднений начинающих спортивных тренеров, определения профессиональных трудностей тренеров по плаванию, путей преодоления трудностей тренеров по синхронному плаванию, затруднений, связанных с формированием дидактической культуры тренера и др. [1-4]. Так как качество взаимодействия тренера и спортсмена закладывает основу успешного тренировочного процесса, затруднения, 
возникающие в осуществлении профессиональной деятельности способны существенно ограничить возможностный и творческий потенциал тренера [4].

Цель исследования: выявить профессиональные затруднения тренеров по игровым и неигровым видам спорта.

На основе анализа требований профессиональных стандартов «Тренер» и «Тренерпреподаватель» к трудовым функциям, федеральных стандартов по видам спорта - к различным сторонам подготовленности спортсменов, в том числе к содержанию тренировочного процесса и организации соревновательной деятельности нами была разработана анкета (25 вопросов) для выявления профессиональных затруднений тренеров.

В социологическом опросе приняли участие 36 человек: 15 (8 женщин и 7 мужчин 2056 лет) - тренеры по игровым видам спорта КГБУ «Спортивная школа «Академия игровых видов спорта Пермского края»») (футбол, волейбол, хоккей, регби) и 21 (15 женщин и 6 мужчин 20-53 лет) - тренеры по неигровым видам спорта МАУ «Спортивная школа олимпийского резерва Кировского района» г. Перми (легкая атлетика, дзюдо, бокс, кикбоксинг, плавание, спортивная гимнастика). 67\% опрошенных тренеров по игровым видам спорта имеют стаж работы не более 5 лет. В группе тренеров по неигровым видам спорта - 33\% - молодые тренеры, проработавшие не более $3 x$ лет, такой же процент составляют респонденты, имеющие стаж работы более 20 лет. 75 \% всех опрошенных имеют высшее образование по направлению «Физическая культура и спорт», 25\% - среднее профессиональное образование в этой же сфере.

Практически все тренеры по неигровым видам спорта $(95,2 \%)$ работают с группами начального этапа подготовки (НП); имеют спортсменов, занимающихся на тренировочном этапе (ТЭ)- 52\% респондентов, этап совершенствования спортивного мастерства (ССМ)- 19\%, и один тренер осуществляет подготовку на этапе высшего спортивного мастерства $(0,8 \%)$. Соответственно тренеры по игровым видам спорта: этап НП - 46,7\%, ТЭ - 40\%, ССМ - 13,7\%.

Большинство опрошенных считают, что наибольшие трудности возникают у тренера при работе с группами этапа начальной подготовки (игровые виды спорта - 53\%, неигровые 71,4\%), однако, тренеры, имеющие опыт работы со спортсменами, тренирующимися на этапах ССМ и ВСМ, относят основные проблемы к этим этапам (игровые виды спорта - 20\%, неигровые - 19\%).

Целью спортивной подготовки является достижение максимально возможного для конкретного спортсмена уровня технико-тактической, физической и психической подготовленности, обусловленного спецификой вида спорта и требованиями достижения максимально высоких результатов в соревновательной деятельности. Большинство респондентов отмечают особые трудности при осуществлении психологической подготовки воспитанников (игровые виды спорта - 46,7\%, неигровые - 61,9\%), на второе место по возникающим сложностям тренеры игровых видов спорта относят тактическую (33\% опрошенных) и техническую подготовку (33\%); у 23,8\% тренеров по неигровым видам спорта возникают трудности при работе над технической подготовленностью воспитанников, у 9,5\% - над физической подготовленностью, 0,5\% - тактической подготовленностью. 20\% и 33,3\% респондентов могут выявить ошибки в процессе выступления спортсменов, но испытывают трудности при оказании помощи спортсменам в смене тактических действий.

Большинство тренеров указывают на затруднения в процессе совершенствования физической подготовленности при развитии гибкости у занимающихся (игровые виды спорта - 46,7\%, неигровые - 38,1\%). У 20\% тренеров по игровым видам спорта возникают трудности при развитии координационных способностей, также у 20\% опрошенных - при работе над развитием быстроты, $13,3 \%$ - совершенствованием выносливости, $6,7 \%$ - силовых 
способностей. 33,3\% опрошенных тренеров по неигровым видам спорта обращают внимания на затруднения, возникающие при развитии выносливости и быстроты (тренеры по дзюдо и плаванию), 28,6\% - координационных способностей (тренеры по боксу и дзюдо), 14,3\% - силы (по плаванию).

В процессе совершенствования технической подготовленности спортсменов 40\% тренеров игровых видов спорта указывают на затруднения при совершенствовании технических элементов, выполняемых в нападении, также $40 \%$ респондентов указали на проблемы при совершенствовании приемов защиты, 13,3\% - техники блокирования, 0,7\% технической подготовки вратарей. В противовес $-81 \%$ тренеров неигровых видов спорта ответили, что не испытывают проблем в процессе совершенствования технической подготовленности занимающихся. Однако были даны следующие одиночные пояснения: возникают трудности в объяснении техники выполнения упражнения, проблемы с логикой выстраивания тренировочного процесса при обучении и совершенствовании техники, трудности с работой с юными спортсменами.

В процессе совершенствования психологической подготовленности спортсменов трудности с поддержанием эмоционального состояния спортсменов испытывают 33,3\% тренеров по игровым видам спорта и $38,1 \%$ тренеров по неигровым видам спорта; 28\% тренеров по неигровым видам спорта указали на проблемы с мотивацией спортсменов на соревнования, настраиванием спортсмена на старт - 9,5\%, умение раскрыть резервные возможности спортсмена - 23,8\%. Тренеры по игровым видам спорта отметили затруднения, связанные с сохранением спокойствия в экстремальных ситуациях $13,3 \%$, также с настроем (настраиванием) спортсменов на игру.

В процессе тренировок и соревнований тренеры используют формы психологопедагогической поддержки, представленные в таблице.

Таблица

Формы психологической поддержки, используемые тренерами

\begin{tabular}{|l|c|c|}
\hline \multicolumn{1}{|c|}{$\begin{array}{c}\text { Формы психолого- } \\
\text { педагогической поддержки }\end{array}$} & $\begin{array}{c}\text { Тренеры по игровым видам } \\
\text { спорта }\end{array}$ & $\begin{array}{c}\text { Тренеры по неигровым видам } \\
\text { спорта }\end{array}$ \\
\hline 1. Поощрение & $86,7 \%$ & $85,74 \%$ \\
\hline 2. Просьба & $66,7 \%$ & $47,6 \%$ \\
\hline 3. Требование & $60 \%$ & $85,74 \%$ \\
\hline 4. Внушение & $53,3 \%$ & $61,9 \%$ \\
\hline 5. Наказание & $33,3 \%$ & $42,9 \%$ \\
\hline 6. Принуждение & $0,7 \%$ & $14,3 \%$ \\
\hline
\end{tabular}

Все респонденты обеих опрошенных групп прибегают к использованию поощрения (86,7\% - тренеры игровых видов спорта и 85,74 - неигровых видов спорта), по гендерному признаку ответы распределились следующим образом: тренеры женщины - 91\%, мужчины $77 \%$; просьбой чаще пользуются тренеры игровых видов спорта $(66,7 \%$ по сравнению с неигровыми - 47,6\%). Требование как форму психолого-педагогической поддержки используют чаще тренеры по неигровым видам, при чем из общего числа опрошенных 92\% мужчин активно используют данную форму и $62 \%$ - тренеры-женщины. К внушению прибегают в равной степени все респонденты; к наказанию - $27 \%$ тренеров-женщин по игровым видам спорта и 45\% - по неигровым видам, $62 \%$ тренеров-мужчин также используют эту форму в тренировочном процессе. Принуждение чаще используют тренеры по неигровым видам спорта, из общего числа опрошенных 4\% составляют тренеры-женщины и 23\% тренеры-мужчины. 
Для управления предсоревновательными и соревновательными состояниями спортсмена большинство тренеров используют советы-наставления (73\% - игровые виды спорта, 61,9 - неигровые). Советы-подсказки во время соревнований более популярны у тренеров по неигровым видам спорта (52,4\% по сравнению с 26,7\%), большинство - это тренеры по единоборствам, которые прибегают к подсказкам во время поединка. Большинство тренеров-женщин используют советы-наставления - 74\%, советы-подсказки - 26\%. $54 \%$ тренеров-мужчин используют первую форму секундирования (наставления), 46\% - вторую.

При работе со спортсменами все тренеры учитывают их индивидуальные особенности. В связи с этим большинство респондентов (53,3\% - игровые виды, $60 \%$ - неигровые) ведут себя более эмоционально, тактику более сдержанного общения используют 46,7\% тренеров по игровым видам спорта и 40\% - по неигровым. По гендерному признаку получили примерно равные распределения - 57\% тренеров-женщин и 53\% тренеров-мужчин ведут себя более эмоционально, соответственно 43\% и 47\% - ведут себя более сдержано.

Следующий показатель, который анализировался нами - отличается ли манера общения тренера со спортсменами разного социометрического статуса. Абсолютное большинство опрошенных (86,7\% - игровые виды, 85,7\% - неигровые) используют одинаковую манеру общения с лидерами и аутсайдерами. Около $14 \%$ респондентов предпочитают общаться по-разному, обосновывая это тем, что у лидера и аутсайдера разная мотивация и разные характеры, соответственно необходимо выбирать разные подходы. Среди этих ответов были такие, как - с лидерами надо общаться жестче, чтобы не было соблазна у лидеров зазнаваться, а с аутсайдерами - мягче, больше хвалить и поддерживать.

$46,7 \%$ тренеров по игровым видам спорта и $28,6 \%$ тренеров по неигровым видам спорта испытывают трудности при работе с женскими командами. Эти проблемы в большинстве возникают у тренеров-мужчин (69\% респондентов), лишь 17\% опрошенных тренеров-женщин указали на трудности, связанные со специфичностью женской психологии. 66,7 \% тренеров по игровым видам спорта и 42,9\% - по неигровым считают, что спортсменки более тревожны, эмоциональны, недоверчивы, конфликтны по сравнению с спортсменами-мужчинами. В группе тренеров по неигровым видам спорта 54\% респондентов отметили наоборот большую эмоциональность мужчин, возможно это объясняется тем, что это были ответы тренеров по боксу и дзюдо, где мужчины-спортсмены демонстрируют больше эмоций, чем в индивидуальных видах спорта.

$26,7 \%$ и 14,3\% респондентов (тренеров по игровым и неигровым видам спорта соответственно) испытывают трудности с выбором тона, формы общения в зависимости от психологического состояния и особенностей спортсмена. У 13,3\% тренеров по игровым видам спорта возникают трудности при подборе средств и методов тренировки в соответствии с возрастными особенностями спортсменов - по причине (как определяют сами) отсутствия профессионального опыта. При возникновении трудностей в процессе профессиональной деятельности 53,3\% и 76,2\% респондентов обращаются к специальной литературе, $40 \%$ и 47\% тренеров стараются найти ответы принимая участие в конференциях и методических семинарах, 66,7\% тренеров по неигровым видам спорта (6\% респондентов тренеров по игровым видам спорта) решают свои проблемы в процессе общения с коллегами, 9\% всех опрошенных используют для этого интернет-ресурсы.

Наибольшие трудности испытывают тренеры в процессе подготовки спортсмена к конкретным соревнованиям (40\% и 42,9\%), проблемы при планировании тренировочного процесса возникают у 33,3\% всех опрошенных, сложности при комплектации групп возникают у 13,3 \% тренеров по игровым видам спорта и 26,8\% - по неигровым видам спорта; 
13,3-14,3\% респондентов рассказали о трудностях при обеспечении профилактики травматизма.

Указали на трудности, связанные с отсутствием должного уровня материально технической базы 20\% и $57,1 \%$ респондентов, недостаточность профессионального опыта $33,3 \%$ всех опрошенных тренеров, 26,7\% тренеров по игровым видам спорта и 19\% - по неигровым - отметили низкий уровень своих знаний, отсутствие профессионального образования и связанных с этим проблем выявлено у 20\% и 3,3\% респондентов.

На нехватку базовых знаний в области психологии указали $60 \%$ и 66,7\% опрошенных, анатомии и физиологии - 38,1\% тренеров по неигровым видам спорта и $20 \%$ по игровым, педагогики - 9,5\% и $20 \%$.

$6 \%$ и 14\% респондентов указали на трудности в процессе своей работы при взаимодействии с руководством учреждения. Не устраивает финансирование, осуществляемое учреждением для обеспечения спортивной подготовки 53,3\% и $81 \%$ респондентов.

У $20 \%$ и $9,5 \%$ опрошенных тренеров возникают трудности при общении с родителями юных спортсменов: отсутствие желания родителей понять своего ребенка и учитывать мнение тренера, не заинтересованы в спортивном росте своего ребенка, родители «далеки» от спорта.

$86,7 \%$ и 85,7\% опрошенных тренеров считают, что не все спортсмены мотивированы на полную отдачу в тренировках и достижение наивысшего результата: в связи с этим всех тренеров огорчает, тот факт, что малая доля спортсменов мотивирована на занятия. Несмотря на это, всем тренерам нравиться передавать свой опыт спортсменам.

Сравнительный анализ профессиональных затруднений тренеров по игровым и неигровым видам спорта позволил выявить следующее:

1. Обе группы тренеров испытывают трудности с подготовкой юных спортсменов на этапе начальной подготовки (И - 53\%, НИ - 71\%); трудности в процессе подготовки спортсмена к конкретным соревнованиям (40\% и 42,9\%), при планировании тренировочного процесса (33,3\% и 33,3\%), сложности при комплектации групп (13,3\% и 26,8\%), при обеспечении профилактики травматизма (13,3-14,3\%).

2. Наибольшие затруднения возникают при работе над психологической подготовленностью спортсменов $(46,7 \%$ и 61,9$)$ : все испытывают трудности с поддержанием эмоционального состояния спортсменов и настраиванием спортсмена на соревнование, считают, что спортсмены не мотивированы на полную отдачу в тренировках и достижение наивысшего результата $(86,7 \%$ и $85,7 \%)$, тренеры по неигровым видам спорта имеют проблемы с выбором подходов к спортсмену для того, чтобы помочь ему раскрыть его резервные возможности; тренеры по игровым видам спорта указывают на проблемы с обучением спортсменов сохранять спокойствие в экстремальных ситуациях.

3. Рассматривая различные стороны подготовленности спортсменов, на второе место (после психологической) по возникающим затруднения тренеры по игровым видам спорта выносят технико-тактическую подготовленность (33,3\%), тренеры по неигровым видам спорта - техническую $(23,8 \%)$.

4. В процессе совершенствования физической подготовленности все тренеры указали на затруднения при развитии гибкости (46,7\% и $38,1 \%)$; тренеры по неигровым видам спорта выделили трудности в работе над выносливостью и скоростными способностями $(33,3 \%)$.

5. Значительные трудности при работе с женскими командами испытывают тренеры по игровым видам спорта $(46,7 \%)$.

6. Тренеры по игровым видам спорта испытывают трудности при выборе тона, формы общения в зависимости от психологического состояния и особенностей спортсмена. 
7. Тренеры объясняют возникновение затруднений в профессиональной деятельности следующими причинами:

- недостаточное финансирование, осуществляемое учреждением для обеспечения спортивной подготовки (53,3\% и $81 \%)$;

- отсутствие должного уровня материально-технической базы (20\% и 57,1\%);

- недостаточность профессионального опыта (33,3\%);

- нехватка базовых знаний в области психологии (60\% и 66,7\%), анатомии и физиологии (20\% и 38,1\%), педагогики (20\%и 9,5\%).

Результаты проведенного исследования свидетельствуют о наличии специфических трудностей в профессиональной деятельности, связанные со специфическими особенностями вида спорта. Помимо этого, выявлены гендерные различия в затруднениях, испытываемых тренерами. Проведение дальнейшего анализа позволит представить практические рекомендации по совершенствованию образовательного процесса по программам высшего образования, осуществляющих подготовку профессиональных кадров по направлению подготовки «Физическая культура и спорт», дополнительного образования (повышения квалификации) тренеров учреждений спортивной подготовки в соответствии с выявленными проблемами.

\section{Литература}

1. Агибалова М.Р., Каткова А.М. Пути преодоления трудностей начинающих тренеров по синхронному плаванию // Проблемы и перспективы развития спортивного образования, науки и практики: материалы IV очно-заочной научной конференции молодых ученых. (г. Москва, 18 декабря 2019). М., 2020. С. 7-14.

2. Загревский О.И., Дудура И.В. Некоторые аспекты дидактической культуры тренерапреподавателя спортивной школы // Теория и практика физической культуры. 2007. № 3. С. 14-16.

3. Николаев А.Н. Успешность деятельности тренера // Теория и практика физ. культуры. 2003. № 12. С. 29-32.

4. Петрина 3.И., Лазуткина А.А. Психолого-педагогические условия преодоления профессиональных затруднений начинающих спортивных тренеров // Фундаментальные и прикладные научные исследования: актуальные вопросы, достижения, инновации: сборник статей XXIII Международной научно-практической конференции. В 3 ч. (г. Пенза, 15 мая 2019 г.). Наука и просвещение, 2019. С. 155-157.

(C) Старкова Е.В., Юдина Р.Н., Хисматулина К.А., 2021 